Elsevier required licence: (C) <2021>. This manuscript version is made available under the CC-BY-NCND 4.0 license http://creativecommons.org/licenses/by-nc-nd/4.0/

The definitive publisher version is available online at

[https://www.sciencedirect.com/science/article/abs/pii/S161886672100340X?via\%3Dihub] 


\title{
Are green wall technologies suitable for major transport infrastructure construction projects?
}

\begin{abstract}
Many city's current transport infrastructure is deemed to be inadequate for rapid population growth and projected urbanisation, driving an increase in the construction of more efficient and reliable transport infrastructure and networks. However, transport infrastructure projects have negative impacts on the environment, during both the construction and operational phases. Green wall technologies have become an increasing trend within urban areas to combat these impacts, however, their uptake has been limited. This study answers the question of whether green wall technologies are a suitable technology for instilling sustainability into major infrastructure projects. This was achieved by comparing available green wall systems, conducting interviews with leading industry professionals and developing a case study on the possible areas of implementation of green wall technologies within a major multi-billion dollar infrastructure project. The overall benefits and constraints are presented, with insights into how these systems may contribute to sustainability rating tools for infrastructure projects.
\end{abstract}

\section{Keywords}

Green façade, Green Infrastructure, Green wall technologies, Living wall, Transport Infrastructure, sustainability 


\section{Highlights}

Green walls could instil sustainability into major infrastructure projects

Potential design opportunities and drivers for the vertical greening identified

Interviews conducted to obtain stakeholder insights form project professionals

Case study analysed to generate implementation approaches

Opportunities and constrains of each implementation approach discussed 


\section{Introduction}

Transport infrastructure is fundamental for urban growth as it drives the efficient movement of people and resources within large cities (Meersman and Nazemzadeh., 2017). Urbanisation is shaped by providing and improving road and transit systems, however, the rapid increase in global population has placed immense pressure on urban cities to develop their public and private infrastructure (Zhang et al., 2020). For this reason, providing efficient and technologically advanced networks are a priority for local governments to improve the social and economic value of urban cities but often neglects the impacts on the surrounding environment (Searle and Legacy, 2020). Thus, improving the sustainability of major road networks has become an increasing trend within the construction and engineering industry ( $\mathrm{Lu}$ et al., 2019), however, it is often neglected by the designers and engineering teams, or their designs are often only implemented at the end of the project (Ronchi et al., 2020). This causes projects to struggle during the construction phase to implement sustainable practices that were not originally accounted for in the design or the budget (Melo et al., 2020). Since infrastructure construction projects often take 3-5 years to complete, this causes years of damage to the cities' wellbeing and the effects are exacerbated over time (Curtis and Low, 2016).

As with most industries, sustainability rating tools are available for the construction and infrastructure industry (Kaur and Garg., 2019) and are used to measure the sustainable practices throughout the planning, design, construction and operational phases of projects. For Australia, these include the Infrastructure Sustainability (IS) Rating Tool for infrastructure projects and the Green Star Rating System for buildings (Griffiths et al., 2020). Using the IS Rating Tool (ISv1.0), the implementation of green initiatives has the potential to be awarded points for credits such as innovative strategies and technologies (Inn-1), Urban Design (Urb-1), Ecological Value (Eco-1) and reducing discharges to air quality (Dis-4) and noise (Dis-2) (ISCA, 2018). Points are given to a project if evidence is provided to meet the criteria for each 
credit and the project is then rewarded with a grade out of 100 at the Design phase and the AsBuilt phase. The IS Rating Scheme Version 2.0 (ISv2.0) was released in 2018 and introduced the Green Infrastructure (Gre-1) credit, which "rewards infrastructure projects for implementation and/or incorporation of green infrastructure" (ISCA, 2018). The credit criteria requires the project to develop a Green Infrastructure Plan that includes targets and strategies surrounding green infrastructure.

Green walls are a well-researched green infrastructure type that has been increasingly used in cities to incorporate green design and sustainability ideals into new developments (Lu et al., 2020). This is due to their proposed benefits for urban cities including urban heat mitigation (Castiglia Feitosa and Wilkinson, 2020), improved air quality (Paull et al., 2020), noise reduction (Azkorra et al., 2015) and biodiversity provision (Huo et al., 2018). They consist of plants that are grown vertically and supported against the internal or external walls of a building or structure. Although green walls are considered an innovative system, with high perceived value, industry uptake has been slow, potentially due to perceived costs, labour and inaccessibility (Melo et al., 2020). Additionally, there is significant questions of whether the technology is actually "sustainable" (Liberalesso et al., 2020; Raouf and Al-Ghamdi, 2019).

Green wall technologies have been implemented on major transport infrastructure networks around the world in an attempt to reduce the impacts of vehicle and transport emissions. A study by Medl (2017) investigated the performance of a greening system constructed on shotcrete walls along a highway exit in Plon, Austria. Shotcrete has been used on road infrastructure projects for mainly tunnel works, soil stabilisation and backfilling (Concrete Institute of Australia, 2010). The greenery system installed comprised of a steel grid mounted on the existing shotcrete wall at an 85-degree incline with sensors installed to monitor the microclimatic characteristics. Results showed a reduction in temperature fluctuations in summer; and an increased insulation effect in winter. This particular green wall system has 
been recommended for urban areas due to its positive effects on temperature, radiation and landscape aesthetics (Medl et al., 2017).

Similarly, a 77-metre long living wall has been installed at New Street railway station in Birmingham to reduce particulate matter (PM) pollution in one of the busiest railway stations in the UK (Thornes et al., 2017). The free-standing modular living wall hosts seventeen different species of plants and the study found that a wide range of elements were captured by the leaves, mainly typical railway exhaust particles and soil dust. The study also determined that all plant species growing in the living wall had the capacity to capture a considerable amount of particulate pollution from the atmosphere, though careful species selection could be used to optimise the benefits and efficiency of using living walls to combat transport infrastructure air pollution (Weerakkody et al., 2017).

Mexico City’s Via Verde project was implemented to introduce greenery to road infrastructure in an attempt to purify the air quality in the urban city. The project consisted of the construction of vertical gardens on over 1000 concrete columns on the Periferico highway over a 27-kilometer distance (Jenkins, 2018). The project aimed to filter out 27 thousand tonnes of toxic gases, 5 tonnes of suspended dust and 10 tonnes of heavy metals annually for over 25, 000 residents (Vargas-Hernandez and Zdunek-Wielgolaska, 2019). However, Via Verde has come under criticism due to the cost-intensive construction with negligible evidence to show a positive effect on air pollution or to support what the project has promised (Swoboda, 2015). Reiterating the findings of the Birmingham study, only a few species have the capacity to purify the air as aimed by the Via Verde project, however the succulents and plants that were installed are not among them. Via Verde's aim was to provide compact solutions, however some situations are geared towards algae towers or moss walls, as provided by the CityTree initiatives providing moss walls to filter up to 80 percent of pollution particles across European cities (Scully, 2019). 
While green wall technologies have become an emerging trend for urban development projects, research dedicated to green wall technologies and their implementation on transport infrastructure and construction projects remains scarce. The research presented here aims to achieve an understanding of whether green wall technologies can be implemented on road infrastructure projects; determine if they are feasible for the project; and the benefits for its surrounding communities. In doing so, this investigation will provide an understanding of how green walls can be constructed throughout the construction phase of a project as well to minimise the current and future effects, the objectives of which are summarised below:

1. Identify the available green wall systems that can be implemented on infrastructure projects.

2. Consult with professionals working on an existing road infrastructure project to determine feedback industry perspective.

3. Using a case study example, propose systems and methodologies of implementation on current and future infrastructure projects during the construction and operational phases.

\section{Methods}

The methodology for this research project is proposed as a three-stage approach to determine the types of available systems, understand the feasibility of implementation from industry representatives and provide a detailed case study on the implementation of green wall systems on a major infrastructure project.

\section{Comparison of Available Systems}

A desktop study was conducted on the different types of green wall technologies to understand the various systems that are available to infrastructure projects. The existing systems were critically analysed against the considerations detailed in regionally relevant 
technical guides: Victoria's Growing Green Guide (Carpenter, 2014) and the NSW Urban Green Cover Technical Guidelines (NSW Government, 2015). A comparison between each type of system will be presented to contextualise their potential within infrastructure construction projects. The design considerations include the following: structural components, growing medium, plant selection, irrigation system, constructability, and maintenance.

\section{Interviews with Industry Professionals}

Investigation of the feasibility of implementing green wall systems into infrastructure projects were conducted by interviewing industry stakeholders involved at a decision-making level in the case study presented in Stage 3. Those interviewed have a professional experience on major infrastructure projects, and have a background in design, environment and sustainability. Semi structured interviews were conducted, with open-ended questions asked and steered towards understanding the practicality of green wall implementation on the project. The interviews provide insight into sustainability criteria, budget and why project teams are hesitant to implement green infrastructure, with understandings of the constraints of the project described in the case study.

The interviews conducted were analysed to identify emerging themes from interviewee responses and have been categorised into the following themes: 1) Feasibility of green walls by serving an additional purpose, 2) Budget, 3) The role of the client, 4) The need for incentives.

The key insights from each interview will be presented to compare the responses for emerging themes.

\section{Case Study (WestConnex Rozelle Interchange)}

A site analysis was conducted to understand the factors that will influence the design components identified in Stage 1 and informed by the stakeholder engagement in Stage 2 . The 
existing structures present at the site will be used to identify potential areas of green wall implementation.

The WestConnex is a NSW Government initiative to support Sydney's long-term economic growth and relieve road congestion as part of the Sustainable Sydney 2030 Strategy and the Greater Sydney Region Plan. The M4-M5 Link is the final stage of the WestConnex and will be delivered in two stages; Stage 1 will comprise of tunnelling works to connect the New M4 and the New M5 tunnels and Stage 2 will be the construction of the Rozelle Interchange and Iron Cove Link (Figure 1).

This case study focuses on the Rozelle Interchange project delivered by a consortium of contractors. The $\$ 3.9$ billion (AUD) project commenced construction in 2019 and is set to open to traffic in 2023. The WestConnex Rozelle Interchange project has been chosen due to its current progression and the ability to analyse the construction and operational phases of the project, and the large amount of criticism from its surrounding communities: stating noise emissions, low air quality and property value declines (Parliament of New South Wales, 2018).

The site analysis will identify and present the possible areas of implementation on the Rozelle Interchange project. Each possible area of implementation will be investigated, including an opportunities and constraints diagram, the surrounding environment, access for construction and maintenance and drainage and irrigation. This will take into consideration the ideal green wall systems for that area, site analysis and interview responses to ensure that an optimal design solution is presented. The systems will also be assessed against the requirements of the Green Infrastructure (Gre-1) credit as part of the Infrastructure Sustainability (IS) Rating Scheme to discuss its overall feasibility. 


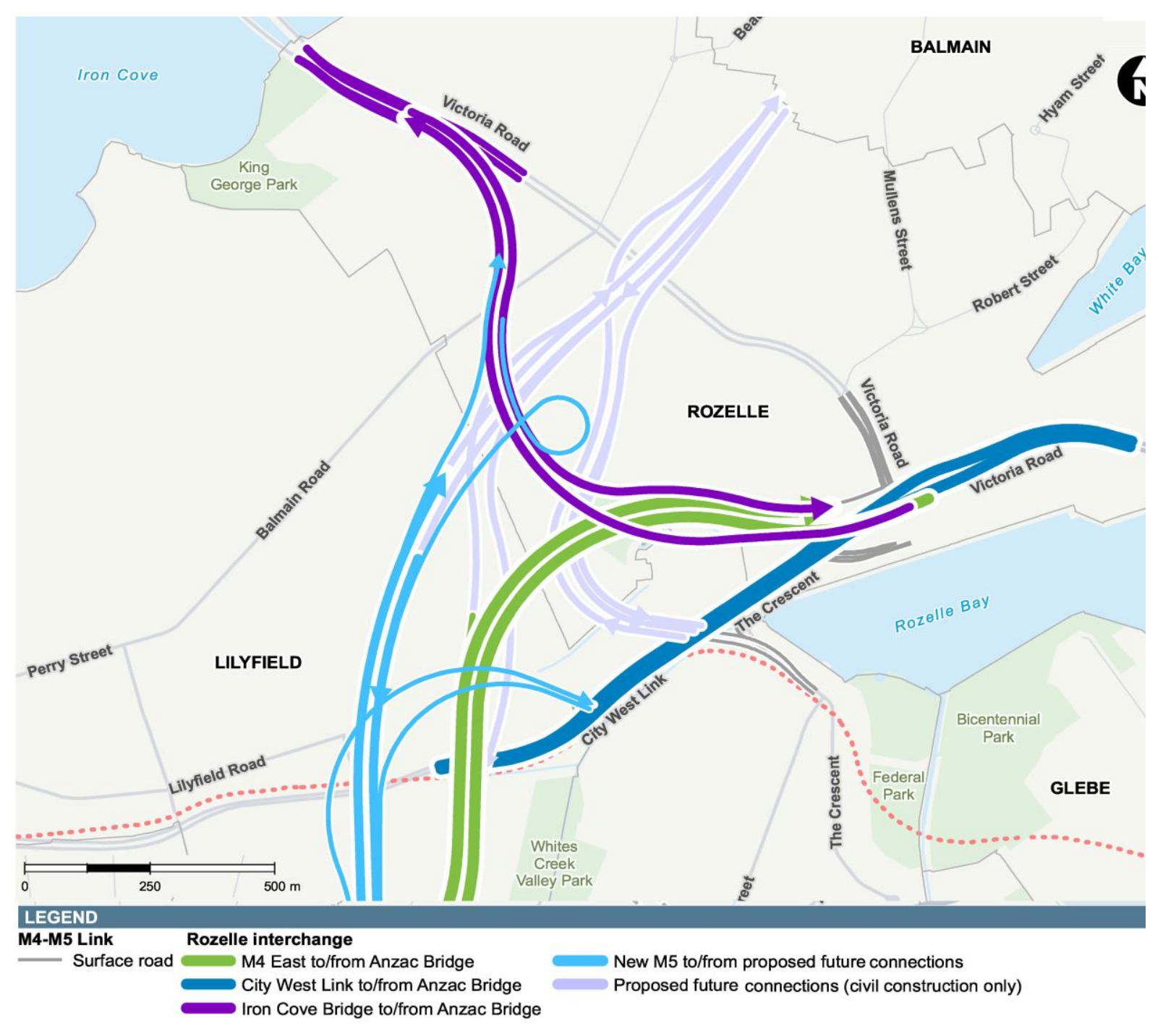

Figure 1 WestConnex Rozelle Interchange and Iron Cove Link Project

\section{Results and Discussion}

\section{Design Considerations}

Living walls and green facades are the two main types of vertical greening technologies that have the potential for implementation on major infrastructure projects (Bustami et al., 2018). This section will describe the different types of systems and the advantages and disadvantages of its design and are presented in Table 1. The main design components include the structure, growing medium, plant selection, drainage and irrigation, constructability and 
maintenance, which will be used to assess the available green wall systems on the market. These factors were considered important with respect to the project and its location, as this will determine the type of system that is most appropriate.

Living wall systems comprise of plants that are pre-grown in modular panels and are fixed vertically to a structural framework or an existing wall (Radić et al., 2019). They are made up of a waterproofing layer, support structure, growing panel, growing media, plants, and irrigation that are all incorporated into one freestanding structure (Douglas et al., 2021). The individual modules allow for a variety of plant species to be installed and the modules are joined to create the desired vegetation cover (State of NSW Office and Environment \& Heritage, 2015). The two main types of living walls include modular systems and hydroponic systems which mainly differ in its growing medium and structure and both systems can vary depending on the desired look and site location. An example includes the previously mentioned 77-metre long living wall installed at New Street railway station, Birmingham UK (Weerakkody et al., 2017).

Green facades are systems where plants are trained to grow vertically along a specifically designed support structure (Douglas et al., 2021). The plants are grown either inground or in planter boxes at the start of the structure and use climbing plants or cascading ground covers to create the desired vegetation cover, typically taking 3-5 years to achieve full coverage. Modular trellis systems and cable net and wire systems are the two main supporting structures that are built as independent structures for the growing plants and are attached to an existing structure or wall. Due to the lower diversity and density of plants, green facades normally require less intensive maintenance and protection than living walls (PérezUrrestarazu et al., 2015). 
Table 1. Comparison of Types of Green Wall Systems

\begin{tabular}{|c|c|c|c|}
\hline Type & Systems & Advantages & Disadvantages \\
\hline $\begin{array}{l}\text { Living } \\
\text { Wall }\end{array}$ & $\begin{array}{ll}\text { - } & \text { Modular } \\
& \text { system } \\
- & \text { Hydroponic } \\
& \text { system }\end{array}$ & $\begin{array}{l}\text { - Wider variety of plant } \\
\text { species } \\
\text { - Complex and aesthetic } \\
\text { designs } \\
\text { - Achieves full } \\
\text { cover and } \\
\text { vegetation after } \\
\text { installation } \\
\text { - Temperature insulation } \\
\text { - Noise attenuation }\end{array}$ & $\begin{array}{l}\text { - Higher waste of materials } \\
\text { - Energy } \\
\text { consumption } \\
\text { due to irrigation } \\
\text { - Needs further } \\
\text { design to ensure } \\
\text { optimisation } \\
\text { - Maintenance and } \\
\text { installation costs }\end{array}$ \\
\hline $\begin{array}{l}\text { Green } \\
\text { Façade }\end{array}$ & $\begin{array}{ll}\text { - } & \text { Modular } \\
\text { - } & \text { Trellis } \\
\text { - } & \text { Cable net and } \\
& \text { wire mesh }\end{array}$ & $\begin{array}{l}\text { - Simple design } \\
\text { - Lack of structural } \\
\text { equipment and } \\
\text { materials } \\
\text { - Light-weight support } \\
\text { structure } \\
\text { - Cost effective } \\
\text { materials } \\
\text { - Easy to install } \\
\text { - Low environmental } \\
\text { burden }\end{array}$ & $\begin{array}{l}\text { - Limited plant } \\
\text { selection and lower } \\
\text { diversity } \\
\text { - Plant selection } \\
\text { affects climate } \\
\text { adaptability } \\
\text { - Slower surface coverage } \\
\text { - Scattered growth } \\
\text { - Maintenance costs }\end{array}$ \\
\hline
\end{tabular}

Although living walls are considered an innovative system with the ability to provide benefits to urban areas beyond aesthetics, industry uptake has been slow due to perceived costs, labour and inaccessibility (Melo et al., 2020). Riley et al. (2019) conducted a study into living walls and stated that although they are necessary for bringing nature to dense urban areas, the systems are costly, and the materials have shorter lifespans than the underlying structure itself. Green wall technologies are relatively new to the transport and infrastructure industry, however green walls in architecture and buildings have a large history dating back to the Babylonians, with the famous Hanging Gardens of Babylon as an ancient wonder of the world (Collins et al., 2017). For this reason, green facades are currently more widely implemented across buildings due to the ease of constructability, low cost and aesthetic in comparison to living 
walls (Ascione et al., 2020). Living wall systems require more research, design, construction and maintenance than a green façade and is still a relatively new concept that is undergoing extensive research into its optimisation (Sendra-Arranz et al., 2020)

\section{Industry stakeholder interviews}

The responses received from interviews conducted are presented in Table 2. A key insight revealed the need for green walls to serve an additional purpose, other than visual amenity, in order for their use to be economically feasible for the project. The Urban Design Manager details the fact that green walls cost more to design, construct and maintain but does not reduce the operational footprint of the project, indicating that the costs to operate and maintain the systems installed outweigh the benefit of visual amenity for the project. The Senior Environment Advisor reiterates this notion by stating that there are other methods of providing visual amenity on infrastructure projects that are far more cost-effective, unless the green walls are explicitly designed for the improvement of air quality, minimisation of noise or reduction of energy consumption.

A key concern was available budget for the construction and operation of green walls, including the costs of operation, maintenance, material use and resource consumption during the operational phase of the project. As a relatively new technology within the construction industry, green walls are often not implemented within the tender and design phase of a project and therefore the costs surrounding its implementation is not forecasted into the costs of the project. This leads to green walls becoming a "last-minute add on" and causing the project to exceed their original budget. However, a key factor in this challenge, and that both stakeholders have mentioned, is that the Contractor will only build what their Client pays for and therefore, will not expend the capital when the Client reaps the operational benefits. The intangible benefits such as promoting biophilia for the project, residents and surrounding communities 
were also not known to the Client or project teams and therefore, is not an influencing factor in the Client/Contractor relationship. The role of the Client is imperative for the implementation of green walls on infrastructure and construction projects, as stated by both stakeholders as with other sustainable concepts seen elsewhere (Mills and Glass, 2009). The WestConnex Rozelle Interchange project requires green walls to be incorporated into its tunnel ventilation outlets through the Infrastructure Planning Approval and Scope of Works and Technical Criteria, as mandated by the Minister of Planning's Approval - Condition E118 and E134 (Negocio Resolutions, 2018). However, both individuals believe that the implementation of green walls should be driven by the Client and incorporated within the contract. The main response was that green infrastructure needs to be driven by the Client so that contractors are obliged to implement green infrastructure, will expend the capital upfront and will account for the technology throughout the tender, design and construction phase of the project.

Additionally, the lack of incentives for infrastructure and construction projects to implement green walls was also raised. It is important for this study to understand whether the industry professionals are aware of any sustainability credits or government incentives that could be used to encourage design and construction teams to implement green walls on the project. The ISCA Rating Scheme does reward projects for incorporating green walls throughout the design and construction phase through sustainability credit points, though, it is easier for projects to gain higher scores in other aspects of the rating scheme to meet their targets rather than attempt to gain credits for Green Infrastructure (Gre-1).

Table 2. Industry stakeholders interviewed that are involved with the project.

\begin{tabular}{lll}
\hline Interviewee & $\begin{array}{l}\text { Project stakeholder with a } \\
\text { background in Design and } \\
\text { Environment }\end{array}$ & $\begin{array}{l}\text { Project advisor on Environment } \\
\text { and Sustainability }\end{array}$ \\
\hline Theme & Key Insights & \\
\hline
\end{tabular}




\begin{tabular}{|c|c|c|}
\hline $\begin{array}{l}\text { Feasibility } \\
\text { of green } \\
\text { walls by } \\
\text { serving an } \\
\text { additional } \\
\text { purpose }\end{array}$ & $\begin{array}{l}\text { Not sustainable if the } \\
\text { system is purely for } \\
\text { aesthetical purposes } \\
\text { - Other cost-effective } \\
\text { ways to provide visual } \\
\text { amenity } \\
\text { - Using systems that } \\
\text { improve air quality } \\
\text { increases the feasibility }\end{array}$ & $\begin{array}{l}\text { - Green walls are not feasible } \\
\text { unless they serve a purpose } \\
\text { other than aesthetical design } \\
\text { - Costs more to design, } \\
\text { build and maintain } \\
\text { - Does not reduce the } \\
\text { operational footprint }\end{array}$ \\
\hline Budget & $\begin{array}{l}\text { - Operational and } \\
\text { maintenance challenges } \\
\text { - } \text { Material and } \\
\text { resource } \\
\text { consumption }\end{array}$ & $\begin{array}{l}\text { The Design and Construct } \\
\text { Contractor will only build } \\
\text { what the Client pays for } \\
\text { - Tangible benefits are not well } \\
\text { known to project teams }\end{array}$ \\
\hline $\begin{array}{l}\text { The role of the } \\
\text { Client }\end{array}$ & $\begin{array}{l}\text { - Required by the project in } \\
\text { the planning approval } \\
\text { - Should be driven by } \\
\text { the Government or } \\
\text { Client } \\
\text { - Projects will find the } \\
\text { budget to implement it if it } \\
\text { is pushed }\end{array}$ & $\begin{array}{l}\text { - Required within the Scope of } \\
\text { Works and Technical Criteria } \\
\text { (SWTC) } \\
\text { - When green infrastructure } \\
\text { is not pushed within the } \\
\text { contract, the Contractor } \\
\text { will not expend the } \\
\text { capital upfront } \\
\text { - Sustainable outcomes need } \\
\text { to be accounted for in the } \\
\text { planning stage, not as a } \\
\text { retrofitting expense at the } \\
\text { end }\end{array}$ \\
\hline $\begin{array}{l}\text { The need for } \\
\text { incentives }\end{array}$ & - Not aware & $\begin{array}{l}\text { - ISCA v2 Green Infrastructure } \\
\text { Credit (Gre-1) }\end{array}$ \\
\hline
\end{tabular}

Site Analysis

Five existing structures that have the potential for green wall implementation on the project were identified. These include:

- Construction hoarding

- Shotcrete batters

- Acoustic Sheds

- Cut and Covers

- Tunnel Ventilation Facilities 
It is important to note that these five structures have been chosen to be investigated within this study as they are structures that are found on almost all major infrastructure and tunnelling projects. The opportunities and constraints of implementing green wall technologies on these five options have been summarised in Table 3.

Table 3. Opportunities and Constraints of the five identified areas that could have green walls

\begin{tabular}{|c|c|c|}
\hline Solution & Opportunities & Constraints \\
\hline $\begin{array}{l}\text { Construction } \\
\text { Hoarding }\end{array}$ & $\begin{array}{l}\text { Located along majority of the } \\
\text { project boundaries allows for a } \\
\text { large surface area } \\
\text { - Visual eyesore for the public } \\
\text { can be improved by } \\
\text { installing green walls } \\
\text { - Can be used to further reduce } \\
\text { construction noise and absorb } \\
\text { vehicle emissions }\end{array}$ & $\begin{array}{l}\text { - Hoarding is constructed out } \\
\text { of low quality/cheap } \\
\text { materials and the green wall } \\
\text { will need additional } \\
\text { structural support } \\
\text { - Access to water for } \\
\text { irrigation may be hard in } \\
\text { some spots along the project }\end{array}$ \\
\hline $\begin{array}{l}\text { Shotcrete } \\
\text { Barriers }\end{array}$ & $\begin{array}{l}\text { - Located along site batters } \\
\text { and has a large surface area } \\
\text { - Often close to drainage systems } \\
\text { - Green walls can improve } \\
\text { erosion and sediment control } \\
\text { - Improve visual aesthetics }\end{array}$ & $\begin{array}{l}\text { - Temporary solution } \\
\text { - Can be prone to } \\
\text { damage from } \\
\text { construction vehicles } \\
\text { - May require increased } \\
\text { maintenance }\end{array}$ \\
\hline Acoustic Sheds & $\begin{array}{l}\text { - Large surface area } \\
\text { - Can assist in absorbing noise } \\
\text { and air pollution } \\
\text { - Water from the tunnel can be } \\
\text { used for irrigation }\end{array}$ & $\begin{array}{l}\text { - Large surface area and } \\
\text { heights can affect } \\
\text { maintenance and access } \\
\text { - High costs for } \\
\text { construction, } \\
\text { installation and } \\
\text { maintenance }\end{array}$ \\
\hline $\begin{array}{l}\text { Tunnel } \\
\text { Ventilation } \\
\text { Facilities }\end{array}$ & $\begin{array}{l}\text { - Reduce vehicle } \\
\text { emissions from surface } \\
\text { road networks } \\
\text { - Improve visual eyesore and } \\
\text { increase biophilia for } \\
\text { residents } \\
\text { - Create visually appealing } \\
\text { structural designs }\end{array}$ & $\begin{array}{l}\text { - Maintenance and access } \\
\text { conditions affected by } \\
\text { large heights } \\
\text { - Often require extensive } \\
\text { design and planning }\end{array}$ \\
\hline Cut and Covers & $\begin{array}{l}\text { - Reduce vehicle emissions and } \\
\text { provide noise abatement for } \\
\text { residents } \\
\text { - Visual interest for drivers } \\
\text { - Permanent structures will have } \\
\text { a long lifespan }\end{array}$ & $\begin{array}{l}\text { - Requires extensive } \\
\text { design and planning } \\
\text { - May affect Crime Prevention } \\
\text { Through Environmental } \\
\text { Design (CPTED) principles } \\
\text { - Maintenance and access will } \\
\text { require lane closures }\end{array}$ \\
\hline
\end{tabular}


Possible Areas of Implementation - Construction Phase

Construction Hoarding

Construction hoarding is the use of boards or fences as a physical marking around the perimeter of a construction site and is essential for all construction projects in Australia for safety, security and communication. The project site has constructed hoarding along the project boundaries to act as construction barriers and noise abatement walls. The proposed area of installation on these walls have been shown in Figure 2 as well as the opportunities and constraints of this location depicted in Figure 3. There is potential for green walls to be installed along these walls to further reduce construction noise from the project, absorb vehicle emissions, improve community perception and promote biophilia for community members.

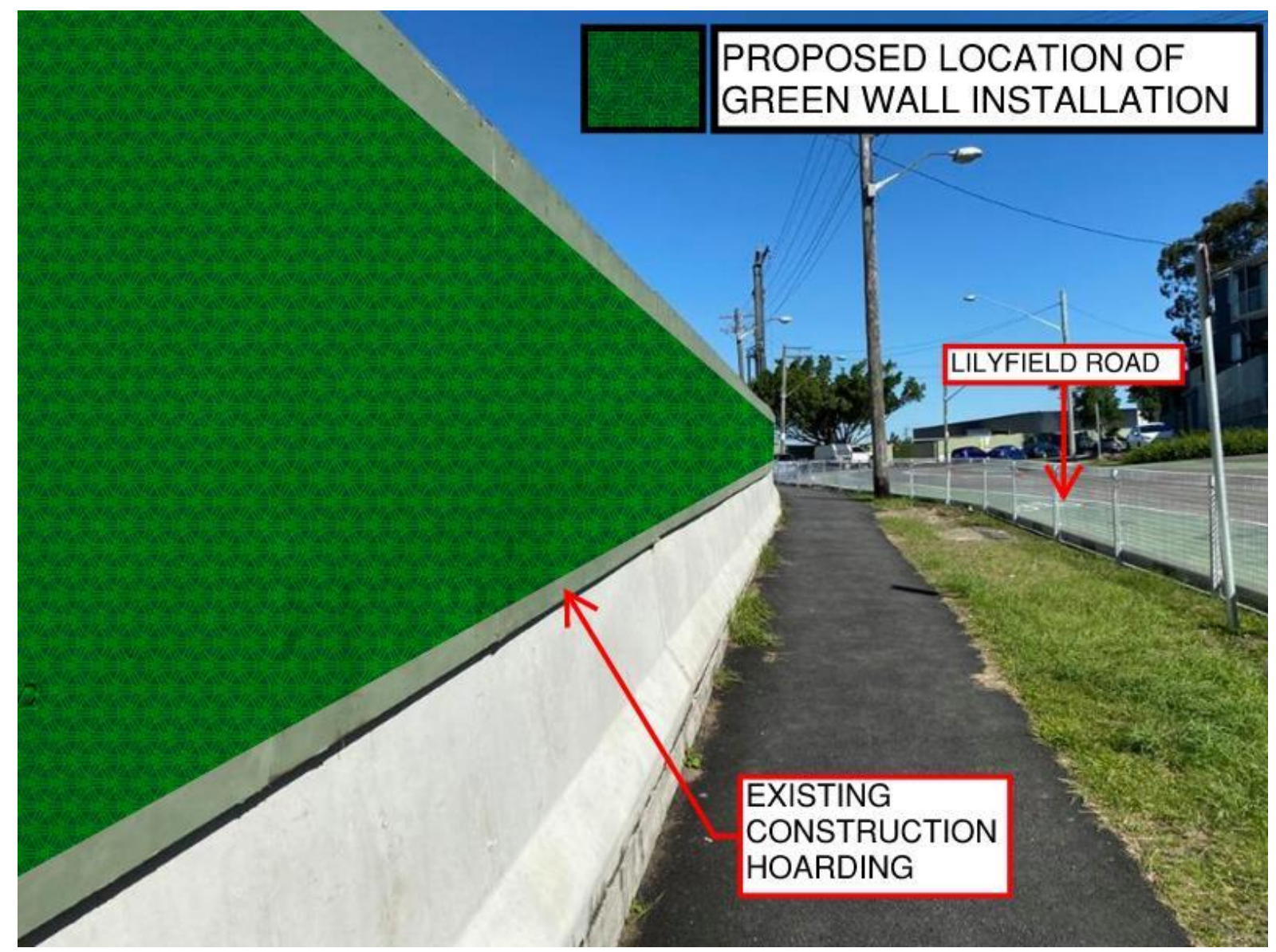

Figure 2 Proposed area of installation - Construction located on Lilyfield Road, Rozelle 
The constraints related to implementing green walls on project boundaries are that these barriers are constructed out of relatively cheap materials (concrete barriers and plywood) for cost savings and will require higher costs to conduct a structural analysis and install green walls. However, since these barriers are often utilised for the entirety of the project (3-5 years for major infrastructure) and is passed by vehicles and the general public daily, it may be worth investing in providing higher quality green walls that can reduce the impacts of vehicle emissions and improve public perception of the project. Furthermore, green walls on project barriers will be accessible by the public and may be susceptible to vandalism and tampering.

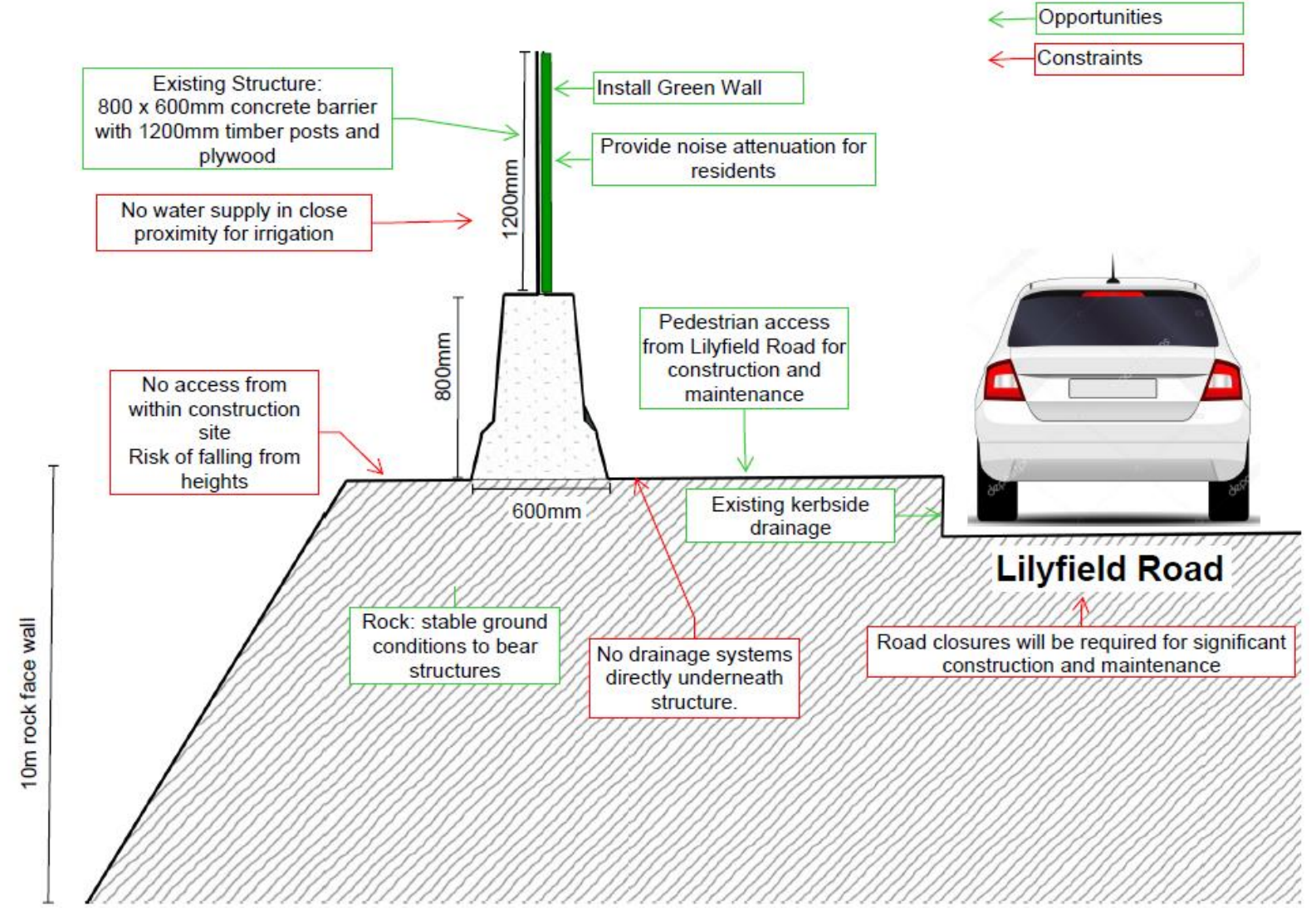

Figure 3 Opportunities and Constraints Diagram - Construction Hoarding

A modular living wall is recommended for installation on construction hoarding, however, it is imperative that a structural analysis is undertaken to understand the load bearing capacity of the wall, the existing walls (often plywood and metal) are either replaced with a stronger material to be able to withstand the additional weight of a green wall, or secondary 
steel structures are used to attach on to the wall (Ling and Chiang, 2018). The installation of green wall structures on construction hoarding will require on-site water tanks to direct rainwater or treated construction water to be used for irrigation. There are often no drainage systems directly under the hoarding, therefore water at the very bottom of the system would need to be redirected into an existing system (e.g. street gutter). Waterproofing membrane is also critical due to the use of a modular living wall and will assist in protecting the wall structure from deteriorating due to the moisture and organic material within the green wall. ISCA credit points can be achieved through this installation by acting as a noise barrier for all construction works (Env-2) and assist in reducing the impacts of air pollution within transport corridors (Env-4).

\section{Shotcrete Batters}

Shotcrete is a form of concrete that is widely used within the civil construction, tunnelling and mining industries. Although the Rozelle Interchange project mostly uses shotcrete during construction of the tunnels, shotcrete can also be used for batters to improve stability and prevent erosion within construction sites. An example batter within the site that has been covered in shotcrete to minimise dust deriving from exposed ground material and reduce the need for erosion and sediment controls is present in Figure 4. The opportunities and constraints diagram for the shotcrete batter is also depicted in Figure 5. 


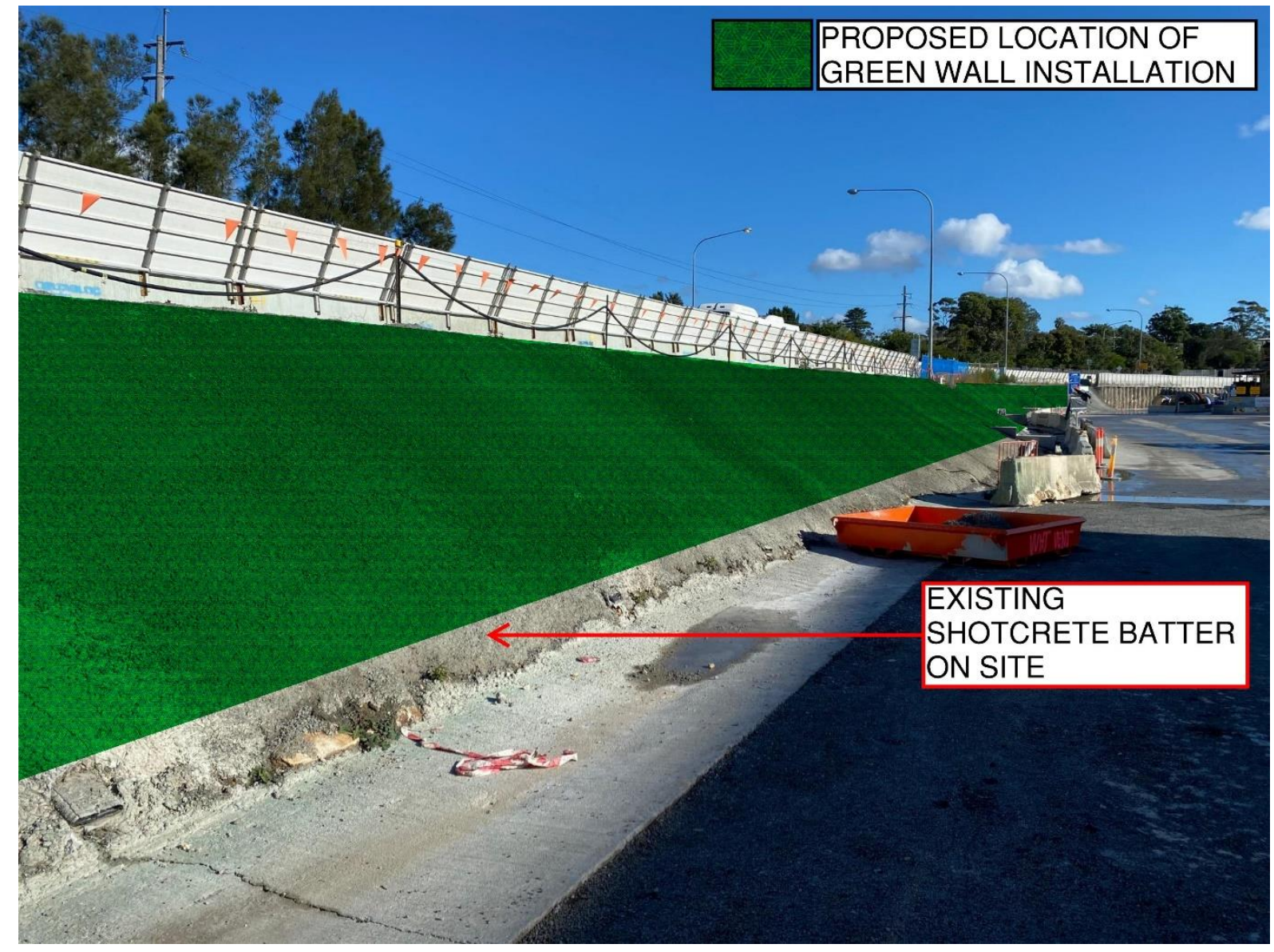

Figure 4 Proposed area of installation - Shotcrete Batter within construction site

Shotcrete batters can be used as a host structure to attach green wall technologies or integrate individual planting modules within the structure, evident in a study undertaken in Plon, Austria (Medl et al., 2017). This can act as a means to improve the visual amenity of the "ugly" and "grey" batters, absorb vehicle emissions and prevent erosion and sediment control within the construction site by filtering stormwater runoff. However, shotcrete batters within the civil construction industry are often only used as temporary measures (Galan et al., 2019), and are prone to damage, thus construction of a green wall will require increased maintenance. 


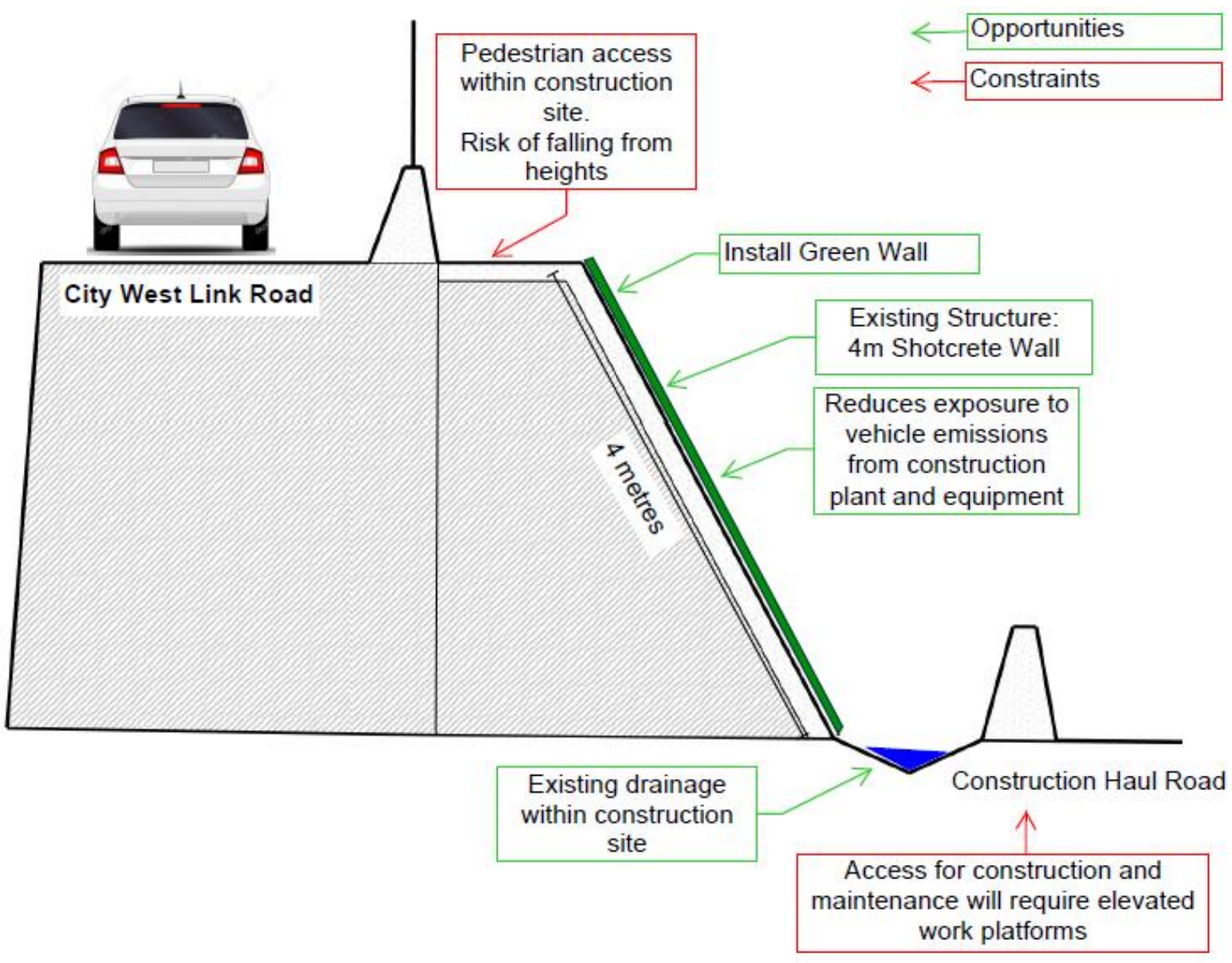

Figure 5 Opportunities and Constraints Diagram - Shotcrete Batter

The recommended design solution for shotcrete batters is to incorporate a green façade system that sits directly on top of the shotcrete batter and uses climbing or hanging plants to produce vegetation cover, especially if the batter is only temporary, as demonstrated by (Medl et al., 2017). Green facades are a cost-effective way to provide visual amenity and requires very little maintenance (Zölch et al., 2019). Planter boxes can be installed at the bottom of the batter and use a cable-net system with climbing plants to achieve vegetation cover over the batter. An irrigation line can run along the line of planter boxes and distribute water nutrients directly to the subsoilThe drip tray system can be installed directly underneath the planter boxes which filters down into a drainage channel that captures excess irrigation and stormwater runoff (concrete swale drain shown in Figure 5) and promote water re-use within the construction site or back into the irrigation system (Prodanovic et al., 2020). This will allow for construction 
and maintenance access from the bottom of the batter at ground level and reduces the need for plant and equipment.

Similarly, the planter boxes can also be situated at the top of the batter using hanging climbing plants but will require additional protective barriers to ensure the safety of the workers. Modular living walls can be designed and incorporated within the structure, however, the capital expenditure incurred will not be feasible for a temporary batter that will be used mainly for visual amenity and stormwater runoff. Implementing green facades could mitigate stormwater runoff, thus contributing to the ISCA credits of receiving water quality (Env-1) by minimising the water captured in stormwater drainage and improving the water quality by filtration (Gimenez-Maranges et al., 2020).

\section{Acoustic sheds}

Acoustic sheds are used across tunnelling projects to minimise noise, dust and light spill that occurs as a result of 24-hour tunnelling works. These sheds are often custom built for every project, depending on the impacts that the project has on the surrounding environment. The Rozelle Interchange site houses three acoustic tunnelling sheds and an example can be seen in Figure 6. The tunnelling sheds have a large surface area, though if green walls were to be installed, they would require early design and planning by the Client and Contractor, with consideration of their duration, as the sheds utilised for the majority of the tunnelling period (2-3 years). 


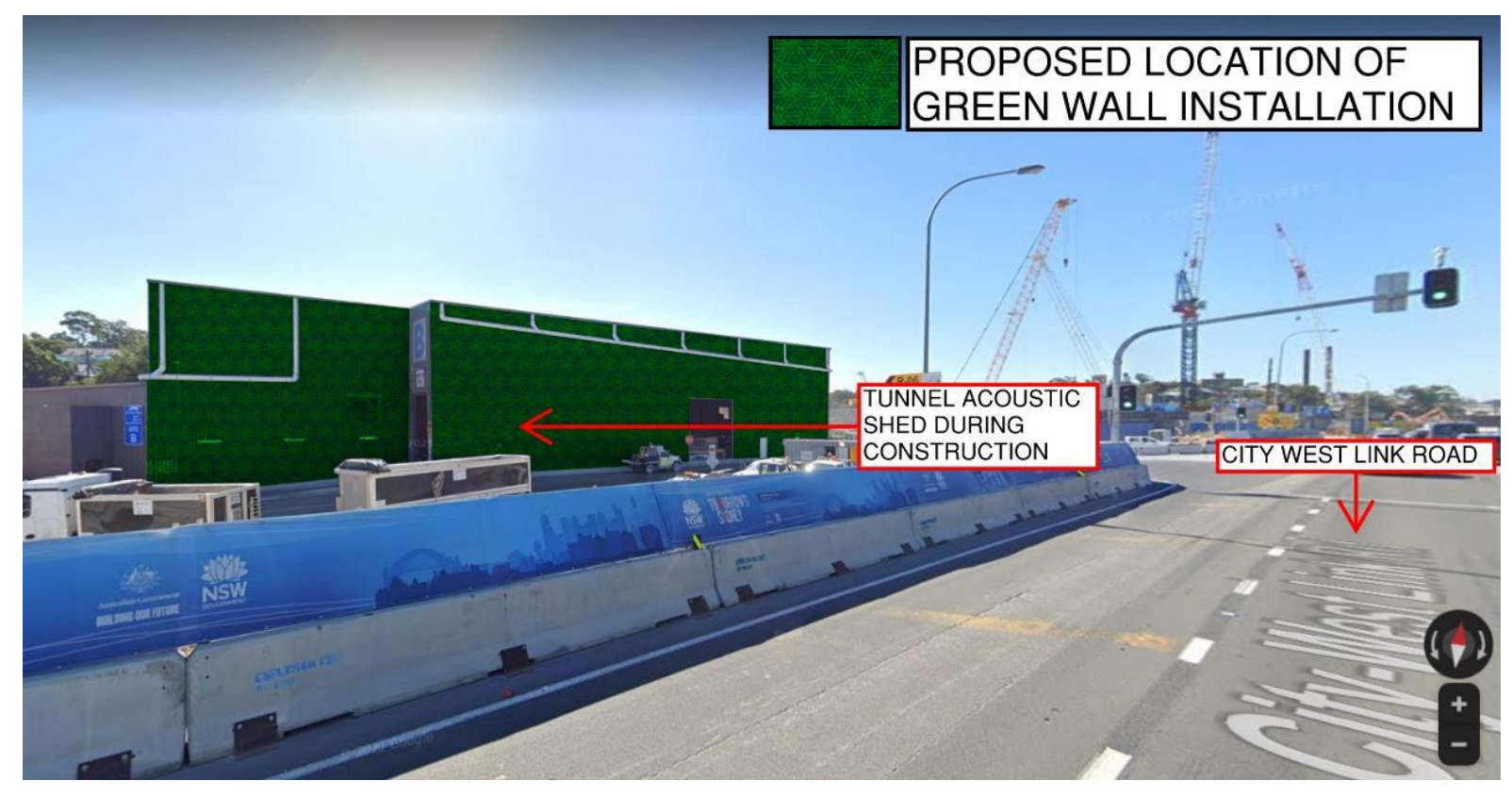

Figure 6 Proposed area of installation - Tunnel Acoustic Shed

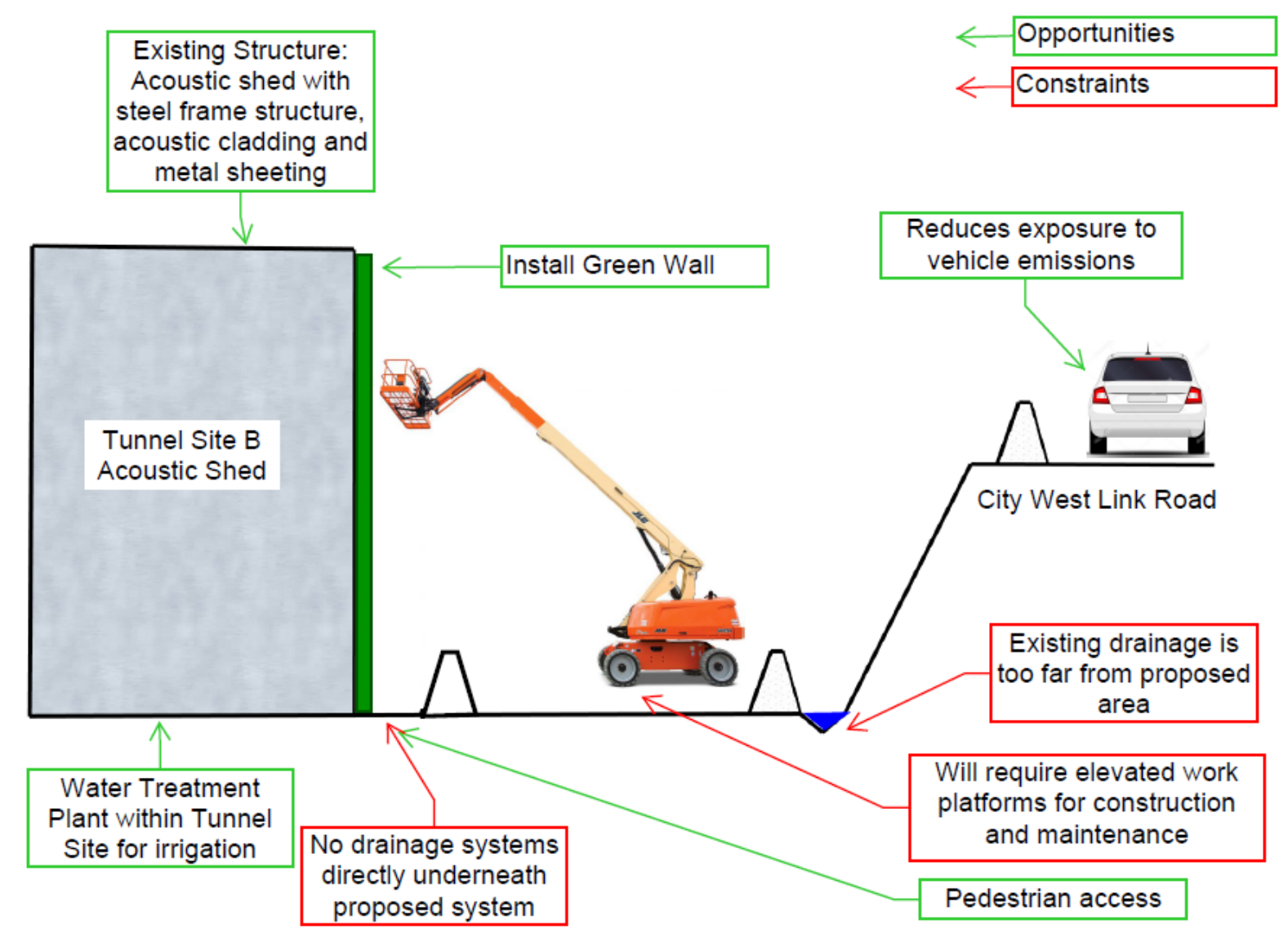

Figure 7 Opportunities and Constraints Diagram - Tunnel Acoustic Sheds 
Acoustic sheds are often constructed using a structural steel frame, acoustic cladding and metal sheeting to separate civil and tunnelling works on-site. Since the structures are used for the entirety of tunnelling works (2-3 years), there is potential for installing semi-permanent green walls onto the structure. The steel components will provide a stable host structure for implementation of green wall technologies; however, a secondary support structure may be required for additional strength.

As shown in Figure 7, the green wall would require the use of elevated work platforms for construction and maintenance, depending on the desired height of the green wall. There are often no drainage systems in proximity of the tunnel shed and it is not feasible for the project to build adequate drainage systems. Water from the system would need to be captured and redirected into the tunnelling water treatment plants or on-site sedimentation basins.

As the structure is semi-permanent, hydroponic or modular living walls are recommended to be installed to achieve full vegetation cover and act at its full potential. Planter boxes should be installed at the maximum height that allows for a safe working height, while still maintaining the ability for the system to absorb construction dust and vehicle emissions from proximal roads. By installing the green walls facing the roadside, ISCA credit points may be achieved through ameliorating air pollution (Env-4). It can also act as a sufficient noise barrier for 24-hour tunnelling works and contribute to minimising noise (Env-2). The water captured and drained from the system can also be reused as dust suppression within the tunnelling shed and minimise the potable water used within the project.

\section{Cut and Covers}

Cut and cover structures are a construction method for building shallow tunnels, involving excavating a large trench in the ground and then covering it with a concrete deck or roof structure. These structures often form the entrance and exit of the tunnel portal and require a carefully assessed design to transition in and out of the tunnels to optimise driver use. An 
example of a green wall implemented on an existing cut and cover structure includes on the Brisbane Airport Link (Figure 8).

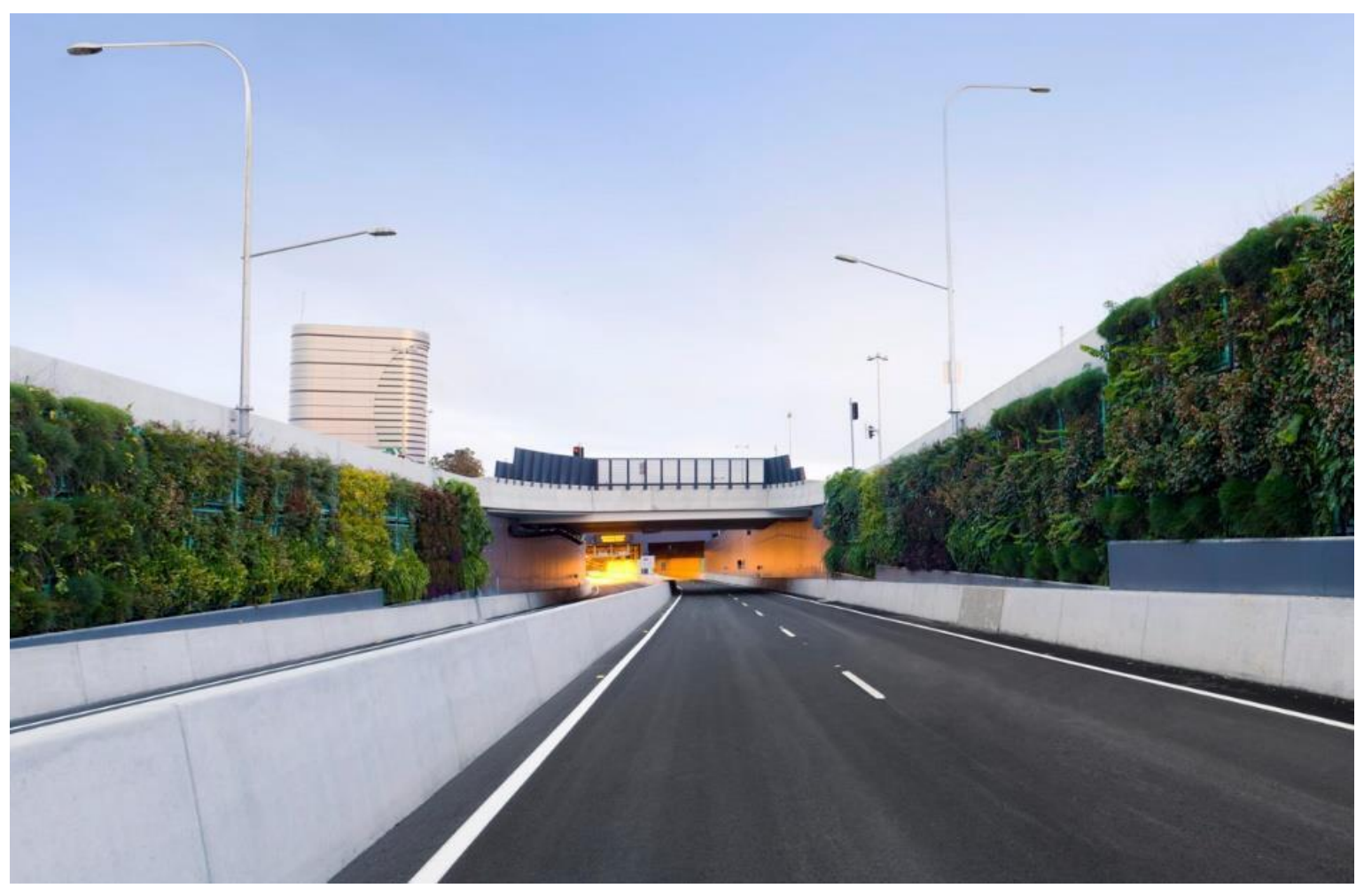

Figure 8 Brisbane Airport Link Cut and Cover 


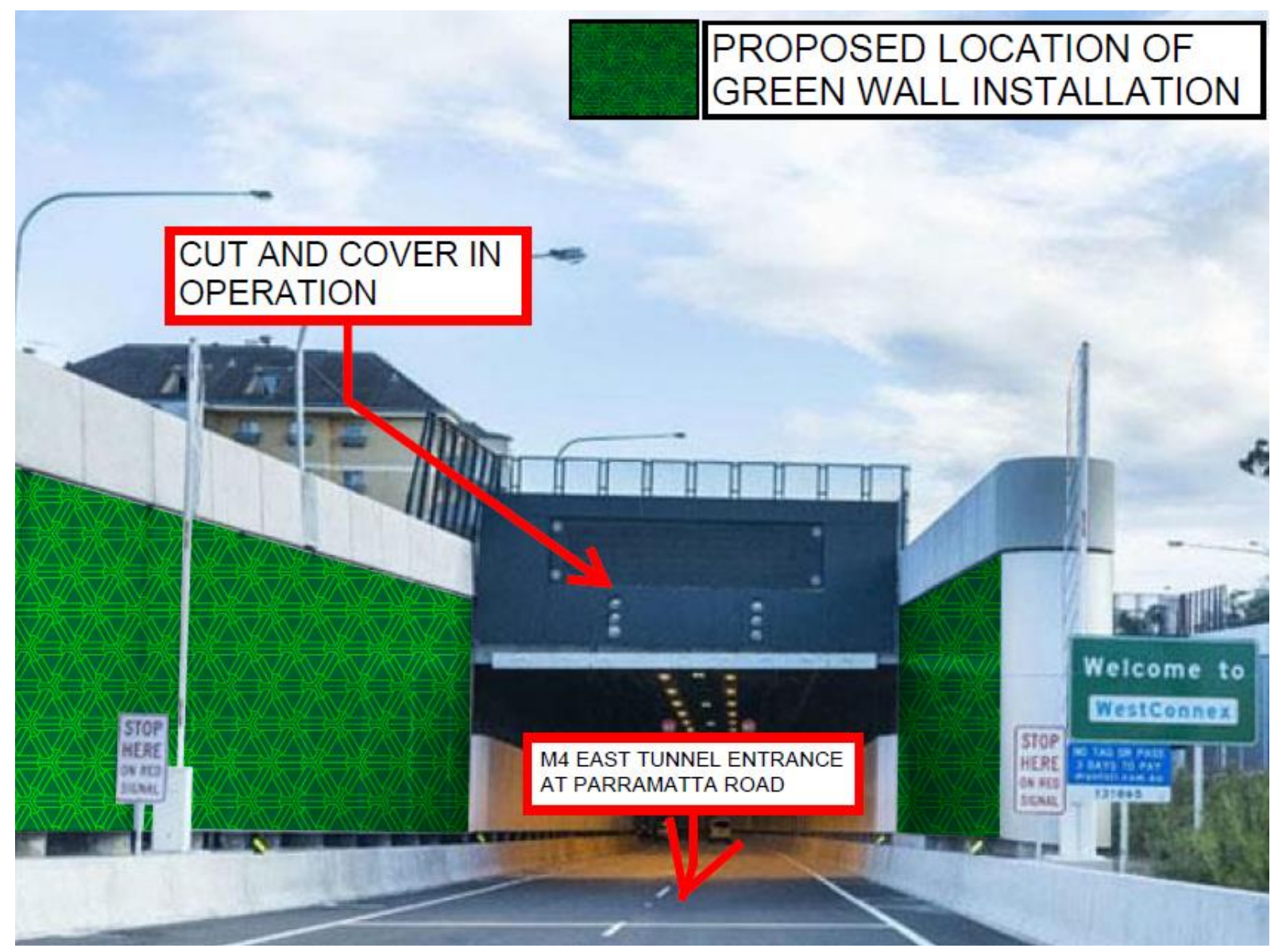

Figure 9 Proposed area of installation - Tunnel entrance

Figure 9 shows a cut and cover structure built on the M4 East project. Cut and covers can be used as a surface for green wall technologies to reduce vehicle emissions and provide a point of interest for drivers. However, implementing green walls on cut and cover structures will require planning, design and approval from various authorities to ensure that the green wall is suitable and safe for drivers. Additional structural analysis will be required to ensure that the system does not impair the structural integrity of the walls and its design lifespan. Monitoring and testing will be required to ensure that the walls absorb particulate pollution from vehicle emissions and do not just act as a visual feature to ensure that it meets the economic benefits. Anti-climb panels are also installed to adhere to Crime Prevention Through Environmental Design (CPTED) guidelines and green wall structures will need to take this into consideration. Further, green walls should only be constructed on the external façade of the 
portal so as to receive natural sunlight. Further research needs to be conducted on the feasibility of whether green walls and plants can survive within the tunnel, but requires additional lighting features (Dominici et al., 2021), enhanced irrigation for nutrients and increased maintenance (Irga et al., 2020).

Road closures and night shifts would be required for maintenance works when the cut and cover is operational. An additional water tank for irrigation would need to be constructed in close proximity to the cut and cover entrance to deliver water and nutrients to the green wall system. Drainage lines are constructed to capture water along the road and throughout the tunnel and is often situated behind the traffic barrier to allow for access if maintenance is required. Drip trays can be used directly underneath the system to capture water used and can direct it into these operational drainage lines or reused for irrigation. If properly implemented and maintained, green wall implementation on cut and covers can achieve the ISCA deliverables for improving air pollution within transport corridors (Env-4) and create a lasting legacy for the community (Leg-1).

\section{Tunnel Ventilation Facilities}

Tunnel ventilation facilities are used to capture vehicle exhaust emissions within a tunnel and released it into the atmosphere using a "smoke stack" (Chang et al., 2020). Longer tunnels require ventilation stacks to regulate the air quality within the tunnel and ensure that it is suitable for human health and are often situated as close as possible to the tunnel portals, usually at the start and the end (Liu et al., 2020). Two ventilation facilities are being constructed within the Rozelle Interchange and Iron Cove Link, one of which will be the largest ventilation structure in the southern hemisphere (Thomy and Merrick, 2018).

There is a negative connotation towards ventilation stacks due to the perceived associated air pollution (Marinello et al., 2020), despite the height of the stacks being designed 
so that the emissions are released and dispersed into the atmosphere at a suitable level that is proposed to not affect human health (Searle and Legacy, 2020). The stacks are also often a visual eyesore for the public and implementing green wall technologies can improve the visual aesthetic and community perception towards the project.

Although there are no available designs proposed for the ventilation structure, Figure 10 outlines an artist impression of the green façade on the ventilation outlets after completion. The lack of available design and other examples of installation in this area at the time of research limited the ability to create an accurate opportunities and constraints diagram.

The constraints relating to the green walls on ventilation stacks identified by the authors include the complexity of the design and the need for early approvals, with the budget forecasted for at the beginning of the project to account for the capital and operational expenditure required for implementation. The ventilation structure will need to be designed with the structural capacity to install a green wall to its façade. This will require ongoing structural analysis and stability inspections to ensure that the green walls have the same lifespan as the ventilation outlet and will minimise the frequency of maintenance. The circular shape of the ventilation stacks will need to be accounted for within the design and access routes will need to be constructed and maintained throughout the entire lifespan of the green wall to allow for maintenance of the wall. 


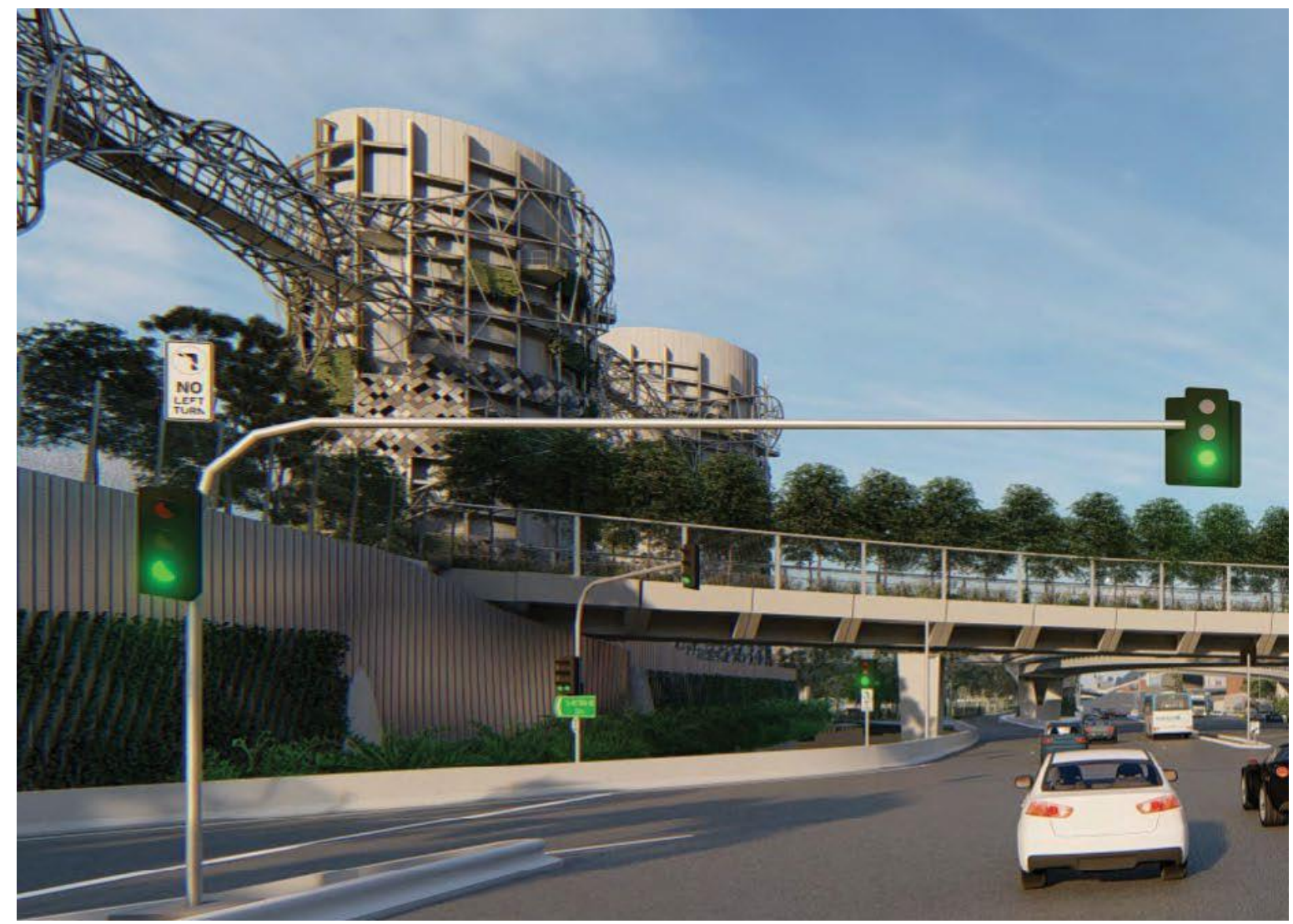

Figure 10 Ventilation Facility with green wall technology panels. - Artist Impression

Since the ventilation stacks have to be quite tall to achieve the required dispersion height (20-40 m), ground level access will not be feasible for green cover along the entirety of the stack. During construction, additional scaffolding and elevated work platforms will be required to construct and install the green walls safely. Maintenance works will also require elevated work platforms as well as permanent stairs and platforms, depending on the height and frequency of maintenance works (Conejos et al., 2019).

Automated irrigation systems should be incorporated within the design that delivers the exact amount of water and nutrients to the planter boxes to reduce the need for frequent maintenance and will require increased analysis from experienced professionals to optimise the green wall system for maximum benefits (Kaltsidi et al., 2020). Drainage systems will also need to be designed underneath the green wall systems as well as multiple drip trays at intervals along the wall. 


\section{Conclusions and further research}

This study answers the question of whether green wall technologies are suitable for implementation on major transport infrastructure projects. By exploring existing green wall technologies, conducting interviews with industry representatives and proposing areas and methods of implementation on an example project, the results provide insight into the importance of implementation during the construction and operational phases of a project.

Living walls and green facades are the two main types of green wall technologies that have been investigated within this study due to their existing implementation and research around the world (Douglas et al., 2021). Living walls installed and studied in Austria and the UK on major transport corridors showed positive impacts on temperature fluctuation and the ability to capture particulate pollution from the atmosphere (Medl et al., 2017; Thornes et al., 2017). However, green facades were found to be more widely implemented in comparison to living walls due to the ease of constructability, low cost and aesthetic (Douglas et al., 2021). Industry uptake of living walls has been slow due to perceived costs, labour and inaccessibility (Melo et al., 2020), however, the system has far more capabilities of improving air quality for urban cities when designed and implemented correctly for transport infrastructure.

The responses received from interviews with industry representatives showed the understanding that green wall technologies can be beneficial for transport infrastructure projects long term. However, responses emphasised that in order to be economically feasible for major infrastructure projects, the green walls need to serve an additional purpose other than visual amenity and need to be explicitly designed for the improvement of air quality, minimisation of noise or reduction of energy consumption. It was also noted that as a relatively new technology within the construction industry, green walls are often not included within the original tender design and the installation costs are not forecasted into the budget, leading to an exceedance in budget when green walls are installed as a "last-minute add on", perpetuating 
the negative connotation and perceived high costs. Both interviewees stated that it was imperative that green infrastructure needs to be driven by the Client so that contractors are obliged to implement green infrastructure, will expend the capital upfront and will account for the technology throughout the tender, design and construction phase of the project.

Utilising interviewee responses and the existing green wall systems, five possible areas of green wall implementation have been identified as suitable areas on many transport infrastructure projects, and analysed for the construction, maintenance and overall feasibility. Table 4 summarises the findings from the case study, regarding the implementation and feasibility of green wall technologies.

Table 4. Possible Areas of Implementation - Feasibility Comparison

\begin{tabular}{|c|c|c|c|c|c|}
\hline Area & eे & $\stackrel{0}{\mathscr{H}}$ & $\sum^{8}$ & $\Xi$ & $\sum^{\overline{0}}$ \\
\hline Green Façade (GF) or Living Wall (LW)? & LW & GF & LW & LW & LW \\
\hline Construction $(\mathrm{C})$ or Operational $(\mathrm{O})$ Phase? & $\mathrm{C}$ & $\mathrm{C}$ & $\mathrm{C}$ & $\mathrm{O}$ & $\mathrm{O}$ \\
\hline $\begin{array}{l}\text { Does the existing structure require additional support } \\
\text { to hold the green wall? }\end{array}$ & $\checkmark$ & & $\checkmark$ & & \\
\hline $\begin{array}{l}\text { Is there available access from the ground to construct } \\
\text { and maintain the system? }\end{array}$ & $\checkmark$ & $\checkmark$ & & & \\
\hline Is there drainage directly underneath the system? & $\checkmark$ & $\checkmark$ & & $\checkmark$ & $\checkmark$ \\
\hline Is there available access to water for irrigation? & $\checkmark$ & $\checkmark$ & $\checkmark$ & $\vee$ & $\checkmark$ \\
\hline Are the walls facing the public? & $\checkmark$ & & $\checkmark$ & $\checkmark$ & $\checkmark$ \\
\hline Are there opportunities for water reuse? & $\checkmark$ & & $\checkmark$ & $\checkmark$ & $\checkmark$ \\
\hline Does it serve an additional purpose? & $\checkmark$ & & $\checkmark$ & $\vee$ & $\checkmark$ \\
\hline Is it feasible for the project? & $\checkmark$ & & $\checkmark$ & $\vee$ & $\checkmark$ \\
\hline
\end{tabular}


Results and comparisons showed that four out of the five possible areas were feasible for implementation and should be used as a baseline for current and future infrastructure projects. This includes construction hoarding, tunnel acoustic sheds, cut and covers and ventilation facilities, due to the fact that these areas can be found on a number of transport infrastructure projects and serve an additional purpose that is significant for projects. Shotcrete batters were deemed as impractical due to the temporary nature of the batters, no additional purpose served other than visual amenity, and the costs of install and maintenance outweigh the minor benefits.

Importantly, construction hoarding and tunnel acoustic sheds are temporary structures however, they are in operation for the entirety of the project and have the capacity to reduce the impacts of vehicles on public roads as well as the impacts of the construction project on the community. Cut and covers and ventilation facilities are permanent structures where although the implementation of living walls may require upfront capital expenditure for design, installation and maintenance, these structures are often designed for a 100-year lifetime. Additional purposes identified, including noise attenuation, improving air quality, reducing energy consumption, reuse of water and improving water quality, can significantly reduce operational costs and are intangible benefits for communities when implemented properly.

It is important to note, this study did not take into account life-cycle analysis for each possible area of implementation. Inclusion of a cost element can provide insight into the economic feasibility of the proposed systems. This can be improved in future research by undertaking extensive analyses of designs at the time of tender for new construction projects to allow for proper consideration into green wall technologies to be implemented throughout the construction and operational phase of a project. Further, this has a transport infrastructure focus, which has relatively little literature available on green walls compared to the building industry. As evidenced by the current work, the main reasons why infrastructure projects are 
hesitant to implement green wall technologies include the lack of knowledge, lack of design standards, lack of regulations and lack of financial support from clients and government authorities. Each of these reasons cause projects to perceive that implementing green walls is difficult and avoid the idea altogether.

This study addresses the gap not only in existing literature, but also the implementation of infrastructure projects by identifying the benefits of green wall technologies within the construction phase of a project. As cities tackle the inevitable growth in population, there will not be numerous construction projects that provide opportunities for the increase in transport infrastructure. This study brings light to the opportunities for green walls to be researched and designed for optimum efficiency for short-term periods.

The authors conclude that green wall technologies can be suitable for major transport infrastructure construction projects if they serve a purpose other than visual amenity and reduce the environmental impacts of the project. This can be done by ensuring that green walls are designed and accounted for at the beginning of a project, optimising the design of the green wall system for each location and ensuring that it can prove to provide a range of benefits for the project. 


\section{References}

Ascione, F., De Masi, R.F., Mastellone, M., Ruggiero, S., Vanoli, G.P., 2020. Green walls, a critical review: knowledge gaps, design parameters, thermal performances and multicriteria design approaches. Energies, 132296.

Azkorra, Z., Pérez, G., Coma, J., Cabeza, L.F., Bures, S., Álvaro, J.E., Erkoreka, A., Urrestarazu, M., 2015. Evaluation of green walls as a passive acoustic insulation system for buildings. Applied Acoustics 89, 46-56.

Bustami, R.A., Belusko, M., Ward, J., Beecham, S., 2018. Vertical greenery systems: A systematic review of research trends. Building and Environment, 146 .226-237.

Carpenter, S., 2014. Growing Green Guide: A Guide to Green Roofs, Walls \& Facades in Melbourne and Victoria, Australia. Australia: State of Victoria, 142.

Castiglia Feitosa, R., Wilkinson, S.J., 2020. Small-scale experiments of seasonal heat stress attenuation through a combination of green roof and green walls. Journal of Cleaner Production 250, 119443.

Chang, X., Chai, J., Luo, J., Qin, Y., Xu, Z., Cao, J., 2020. Tunnel ventilation during construction and diffusion of hazardous gases studied by numerical simulations. Building and Environment 177, 106902.

Collins, R., Schaafsma, M., Hudson, M.D., 2017. The value of green walls to urban biodiversity. Land Use Policy, 64,114-123.

Conejos, S., Chew Michael Yit, L., Azril Fikril Hakim, B., 2019. Green maintainability assessment of high-rise vertical greenery systems. Facilities 37(13/14), 1008-1047.

Curtis, C., Low, N., 2016. Institutional barriers to sustainable transport. Routledge.

Galan, I., Baldermann, A., Kusterle, W., Dietzel, M., Mittermayr, F., 2019. Durability of shotcrete for underground support- Review and update. Construction and Building Materials 202, 465-493.

Douglas, A.N., Morgan, A.L., Rogers, E.I., Irga, P.J., Torpy, F.R., 2021. Evaluating and comparing the green wall retrofit suitability across major Australian cities. Journal of Environmental Management, 298113417.

Dominici, L., Fleck, R., Gill, R.L., Pettit, T.J., Irga, P.J., Comino, E., Torpy, F.R., 2021. Analysis of lighting conditions of indoor living walls: Effects on $\mathrm{CO} 2$ removal. Journal of Building Engineering, 44, p.102961.

Greenroofs (2008) 'Green Roofs for Healthy Cities: Introduction to Green Walls', (September), p. 38.

Gimenez-Maranges, M., Pappalardo, V., La Rosa, D., Breuste, J., Hof, A., 2020. The transition to adaptive storm-water management: Learning from existing experiences in Italy and Southern France. Sustainable Cities and Society 55, 102061. 
Griffiths, K., Boyle, C., Henning, T.F., 2020. Infrastructure sustainability rating toolsexploring opportunities for the engineering profession based on international research. Australian Journal of Civil Engineering 18(1), 18-28.

Francis, J., Hall, G., Murphy, S. and Rayner, J., 2014. Growing Green Guide: A guide to green roofs, walls and facades in Melbourne and Victoria, Australia. State of Victoria through the Department of Environment and Primary Industries

Huo, X., Yu, A.T.W., Wu, Z., 2018. An empirical study of the variables affecting site planning and design in green buildings. Journal of Cleaner Production 175, 314-323.

Irga, P.J., Pettit, T., Shagol, C.C., Kim, K.J., Torpy, F.R., 2020. Chapter 14 Phytosystems implementation: examples of application in practice, in: Soreanu, G., Dumont, É. (Eds.), From Biofiltration to Promising Options in Gaseous Fluxes Biotreatment. Elsevier, pp. 283-299.

ISCA, 2018. ISv2.0 Technical Manual Planning rating. https://www.isca.org.au/Toolsand-Resources (Accessed 17/05/2020).

Kaltsidi, M.P., Fernández-Cañero, R., Franco-Salas, A., Pérez-Urrestarazu, L., 2020. Improving the performance of felt-based living wall systems in terms of irrigation management. Urban Forestry \& Urban Greening 54, 126782.

Kaur, H. and Garg, P., 2019. Urban sustainability assessment tools: A review. Journal of Cleaner Production 210,146-158.

Liberalesso, T., Oliveira Cruz, C., Matos Silva, C., Manso, M., 2020. Green infrastructure and public policies: An international review of green roofs and green walls incentives. Land Use Policy 96, 104693.

Ling, T.-Y., Chiang, Y.-C., 2018. Well-being, health and urban coherence-advancing vertical greening approach toward resilience: A design practice consideration. Journal of Cleaner Production 182, 187-197.

Liu, Q., Nie, W., Hua, Y., Yin, S., Guo, L., Peng, H., Ma, H., Zhou, W., 2020. Investigation of efficient dust control strategy for construction tunnels: Ventilation System's implications for cleaner production. Building and Environment 180, 107032.

Lu, W., Chi, B., Bao, Z., Zetkulic, A., 2019. Evaluating the effects of green building on construction waste management: A comparative study of three green building rating systems. Building and Environment 155, 247-256.

Lu, H., Mayer, A.L., Wellstead, A.M., Zhou, S., 2020. Can the dual identity of policy entrepreneur and policy implementer promote successful policy adoption? Vertical greening policymaking in Shanghai, China. Journal of Asian Public Policy 13, 113-128.

Marinello, S., Lolli, F., Gamberini, R., 2020. Roadway tunnels: A critical review of air pollutant concentrations and vehicular emissions. Transportation Research Part D: Transport and Environment 86, 102478. 
Medl, A., Stangl, R., Kikuta, S.B., Florineth, F., 2017. Vegetation establishment on 'Green Walls': Integrating shotcrete walls from road construction into the landscape. Urban Forestry \& Urban Greening 25, 26-35.

Medl, A. Mayr, S., Rauch, H.P., Weihs, P., Florineth, F., 2017. Microclimatic conditions of "Green Walls", a new restoration technique for steep slopes based on a steel grid construction, Ecological Engineering, 101, 39-45. doi: 10.1016/j.ecoleng.2017.01.018.

Melo, C., Teotónio, I., Silva, C.M. and Cruz, C.O., 2020. What's the economic value of greening transport infrastructures? The case of the underground passages in Lisbon. Sustainable Cities and Society, 56, p.102083.

Meersman, H., Nazemzadeh, M., 2017. The contribution of transport infrastructure to economic activity: The case of Belgium. Case Studies on Transport Policy, 5(2), 316-324.

Mills, F.T., Glass, J., 2009. The Construction Design Manager's Role in Delivering Sustainable Buildings. Architectural Engineering and Design Management 5(1-2), 75-90.

Negocio Resolutions, 2018. WestConnex Community Reference Group Central Dispute Resolution Metting 1, in: lancken, S. (Ed.). WestConnex, 7 -15 Wetherill St Leichhardt https://wcx-

staging.thehallway.co/sites/default/files/WestConnex\%20Community\%20Reference\%20Gro up $\% 20 \% 28$ WCRG $\% 29 \% 20$ Southern $\% 20 \%$ E2\%80\%93\%20Meeting\%203\%2C\%2006\%20N ov\%202018_0.pdf (Accessed 17/05/2020)

NSW Government, 2015. Urban Green Cover in NSW Technical. Office of Environment and Heritage, 59 Goulburn Street, Sydney NSW 2000 PO Box A290, Sydney South NSW 1232.

Parliament of New South Wales, 2018. Impact of the WestConnex Project, in: NSW. (Ed.). https://www.parliament.nsw.gov.au/lcdocs/inquiries/2497/Final\%20report\%20Sydney. $\% 20$ Impact $\% 20$ of\%20the\%20WestConnex\%20Project\%20-\%20FINAL\%20$\% 2014 \% 20$ December\%202018.pdf (Accessed 14/04/2020)

Paull, N.J., Krix, D., Irga, P.J., Torpy, F.R., 2020. Airborne particulate matter accumulation on common green wall plants. International Journal of Phytoremediation 22(6), 594-606.

Prodanovic, V., Hatt, B., McCarthy, D., Deletic, A., 2020. Green wall height and design optimisation for effective greywater pollution treatment and reuse. Journal of Environmental Management 261, 110173.

Radić, M., Brković Dodig, M., Auer, T., 2019. Green facades and living walls-a review establishing the classification of construction types and mapping the benefits. Sustainability, 11, 4579.

Raouf, A.M.I., Al-Ghamdi, S.G., 2019. Building information modelling and green buildings: challenges and opportunities. Architectural Engineering and Design Management $15(1), 1-28$. 
Ronchi, S., Arcidiacono, A., Pogliani, L., 2020. Integrating green infrastructure into spatial planning regulations to improve the performance of urban ecosystems. Insights from an Italian case study. Sustainable Cities and Society 53, 101907.

Searle, G., Legacy, C., 2020. Locating the public interest in mega infrastructure planning: The case of Sydney's WestConnex. Urban Studies, 58(4), 826-844

Sendra-Arranz, R., Oquendo, V., Olivieri, L., Olivieri, F., Bedoya, C., Gutiérrez, A., 2020. Monitorization and statistical analysis of south and west green walls in a retrofitted building in Madrid. Building and Environment, 183, p.107049.

Swoboda, K., Ballhausen, T., Peytchinska, E., 2020. Vía Verde. Greening a Highway in Mexico City. In FLORA (pp. 286-297). De Gruyter.

Thomy, D., Merrick, J., 2018. Design of the Parramatta Road ventilation facility on WestConnex 1B Sydney, Australian Structural Engineering Conference: ASEC 2018. Engineers Australia, p. 220.

Thornes, J.E., Hickman, A., Baker, C., Cai, X., Delgado Saborit, J.M., 2017, April. Air quality in enclosed railway stations. In Proceedings of the Institution of Civil EngineersTransport (Vol. 170, No. 2, pp. 99-107). Thomas Telford Ltd.

Weerakkody, U., Dover, J.W., Mitchell, P., Reiling, K., 2017, Particulate matter pollution capture by leaves of seventeen living wall species with special reference to rail-traffic at a metropolitan station. Urban forestry \& urban greening, 27, 173-186.

Zhang, F., Chung, C.K.L., Yin, Z., 2020. Green infrastructure for China's new urbanisation: A case study of greenway development in Maanshan. Urban Studies, 57, 508524.

Zölch, T., Rahman, M.A., Pfleiderer, E., Wagner, G., Pauleit, S., 2019. Designing public squares with green infrastructure to optimize human thermal comfort. Building and Environment 149, 640-654. 